\title{
Fase Ketiga Teori Manajemen Keuangan: Neurofinance Sebagai Sebuah Pendekatan Baru
}

\author{
Lusianus Heronimus Sinyo Kelen \\ Prodi Manajemen, Universitas Kristen Wira Wacana Sumba \\ sinyokelen@unkriswina.ac.id
}

\begin{abstract}
Abstrak
Artikel ini bertujuan untuk menggambarkan perkembangan disiplin ilmu manajemen keuangan sejak 1844 sampai saat ini serta membahas tentang neurofinance sebagai sebuah konsep baru dalam mengatasi beberapa kelemahan dari pandangan-pandangan atau teori-teori sebelumnya (pandangan tradisional dan perilaku). Artikel ini juga berisikan gambaran terkait neurofinance sebagai sebuah pendekatan baru terkait keuangan berbasis perilaku serta merupakan lintas disipliner antara keuangan, psikologi dan ilmu tentang saraf. Dalam telaah, penulis menunjukkan bahwa saat ini teori manajemen keuangan telah berada pada fase ketiga, dimana fase pertama merupakan pandangan keuangan tradisional, dan fase kedua merupakan pandangan keuangan berbasis perilaku. Studi pustaka digunakan untuk menjelaskan tujuan penulisan dengan mengumpulkan berbagai sumber literatur kemudian dilakukan tinjauan dan telaah.
\end{abstract}

Kata Kunci: Keuangan Berbasis Perilaku, Keuangan Tradisional, Neurofinance.

\begin{abstract}
This article aims to describe the development of financial management disciplines from 1844 to the present and discuss neurofinance as a new concept in overcoming some of the weaknesses of previous views or theories (traditional and behavioural views). This article also contains an overview of neurofinance as a new approach to behaviour-based finance as well as a cross-disciplinary approach between finance, psychology, and neuroscience. In this study, the authors show that currently financial management theory is in its third phase, where the first phase is traditional financial, and the second phase is behaviour finance. A literature study is used to explain the purpose of writing by collecting various literature sources and then conducting a review and analysis.
\end{abstract}

Keywords: Behavior Finance, Traditional Finance, Neurofinance.

\section{PENDAHULUAN}

Perdebatan antara pihak traditional finance dengan behavioral finance memunculkan perkembangan dari teori pada ilmu manajemen khususnya bagian keuangan. Menurut Srivastava et al. (2019) dan Bloomfield (2010), pendekatan tradisional adalah pendekatan yang rasionalis, pandangan ini menjelaskan bahwa manusia dapat mengevaluasi bobot probabilitas hasil di masa depan dan maksimisasi utilitasnya. Sedangkan pendekatan keperilakuan menjelaskan bahwa manusia tidak sepenuhnya rasional sehingga dapat mengambil keputusan yang tidak rasional. Keuangan berbasis perilaku merupakan suatu pandangan yang relatif bertentangan dan merupakan pengembangan dari pandangan dasarnya yaitu tentang rasionalitas. Teori dasar manajemen keuangan menggunakan asumsi-asumsi yang menganggap bahwa manusia adalah rasional dalam mengambil keputusan. Namun, hal ini dianggap tidak sesuai kenyataan karena manusia dapat mengambil keputusan tidak dalam kondisi rasional.

Teori manajemen keuangan meliputi teori utilitas, teori state-preference, teori mean-variance dan CAPM, teori APT, teori option pricing, teorema Modigliani-Miller serta teori EMH (Paddock et al., 1980). Kehadiran teori-teori tersebut didasari dengan pandangan tradisional. Keuangan tradisional menggambarkan tentang harga yang berkembang serta cara terbaik mengalokasikan sumber daya ekonomi ketika pilihan keuangan tidak pasti, dibatasi waktu, berisiko, dan strategis (Miendlarzewska et al., 2019). Namun, pandangan tersebut memiliki kelemahan atau kekurangan, salah satunya terkait asumsi-asumsi yang digunakan. Fenomena atau fakta di lapangan menunjukkan adanya perilaku tidak rasional dari investor atau pelaku keuangan terkait pengambilan keputusan. 
Berkembangnya keuangan berbasis perilaku terus meningkat dari tahun ke tahun, dengan memasukkan wawasan serta pandangan dari ilmu sosial lainnya seperti psikologi dan sosiologi, hal ini menunjukkan bahwa keputusan keuangan seorang investor dipengaruhi oleh emosi, bias psikologis, stres, dan perbedaan individu. Pandangan yang diperoleh dan dampaknya terhadap teori keuangan menyebabkan beberapa peneliti melangkah lebih jauh dan bertanya bagaimana dan mengapa pelanggaran ini muncul di otak dan apakah menggabungkan temuan dari ilmu saraf dapat lebih meningkatkan model yang ada, sehingga memunculkan bidang neurofinance (Miendlarzewska et al., 2019). Sehingga dapat dijelaskan bahwa neurofinance sebagai sebuah pencampuran ilmu kedokteran dan psikologi dengan keuangan.

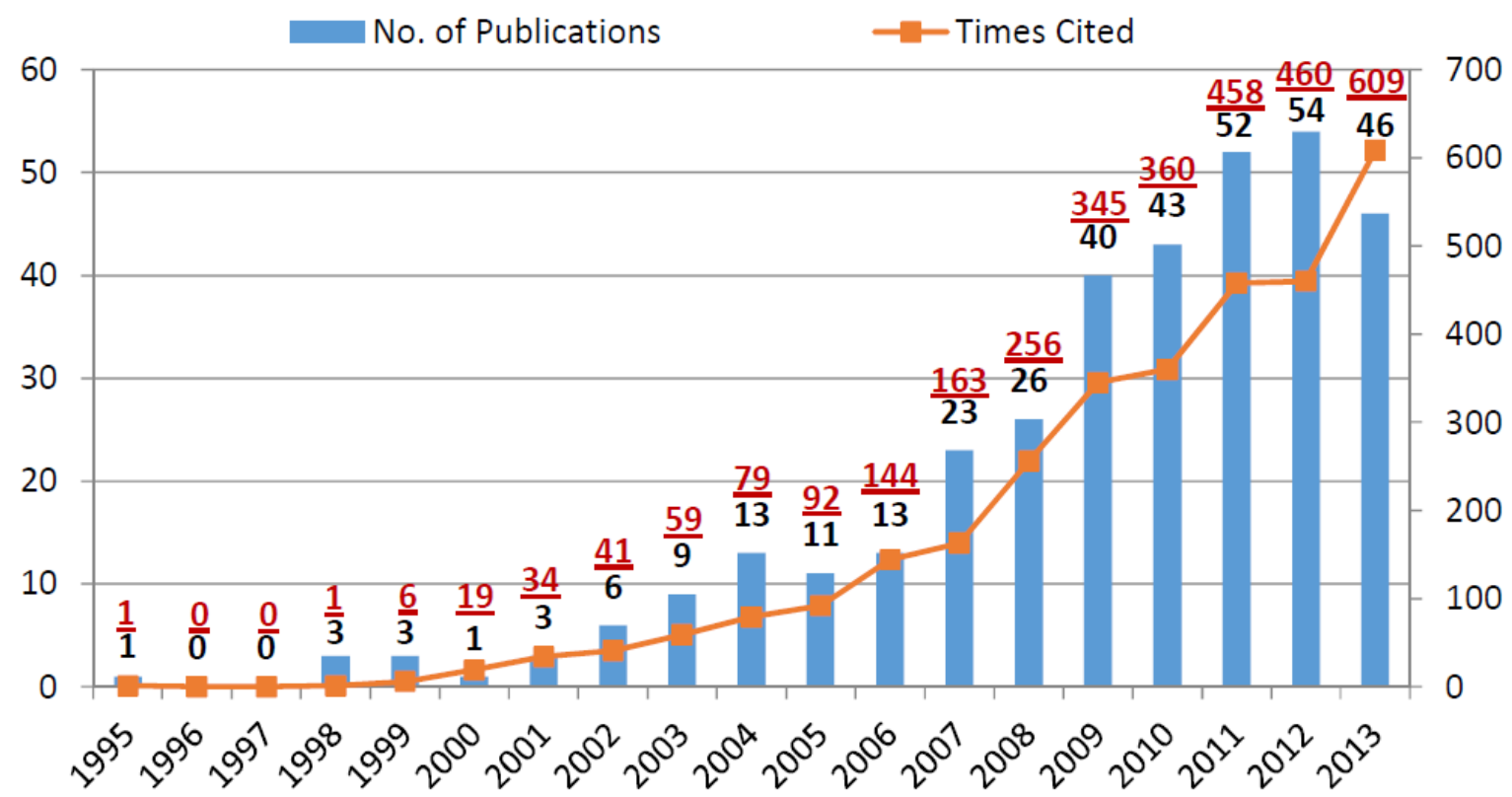

Sumber: Huang et al., (2016)

Gambar 1. Perkembangan Publikasi Penelitian Keuangan Berbasis Perilaku

Sejak tahun 1995 sampai 2013, penelitian terkait keuangan berbasis perilaku semakin meningkat secara signifikan. Hal ini menunjukkan sebuah perkembangan besar ilmu manajemen keuangan telah terjadi. Kemudian Huang et al. (2016) menjelaskan bahwa artikel tentang keuangan berbasis perilaku paling banyak dari negara-negara seperti Amerika Serikat, Jerman, Tiongkok, dll. Hal ini menunjukkan bahwa Indonesia masih sangat sedikit atau dapat dikatakan kurang, penelitian yang dipublikasi.

Artikel ini bertujuan untuk menjelaskan evolusi dan perkembangan keilmuan manajemen keuangan dari pandangan tradisional, keperilakuan sampai pada sebuah konsep atau pandangan baru yang terus berkembang yaitu neurofinance. Menurut Ardalan (2018) neurofinance adalah bidang transdisipliner baru yang menggunakan teknik pengukuran ilmu saraf untuk mengidentifikasi substrat saraf yang terkait dengan keputusan keuangan. Neurofinance bermaksud untuk melampaui keuangan berbasis perilaku, karena menjanjikan untuk mengidentifikasi penyebab fisiologis yang mendasari penyimpangan dari perilaku memaksimalkan utilitas neoklasik.

\section{PEMBAHASAN}

\section{Perkembangan Teori Keuangan}

Menurut Kapoor \& Prosad (2017) pada pertengahan abad kedelapan belas dianggap sebagai titik awal pandangan tradisional mulai berkembang. Teori utamanya adalah teori utilitas yang diharapkan. Di sini, utilitas dianggap sebagai ukuran kepuasan individu dengan mengonsumsi barang atau jasa. Pada tahun 1844, Bernoulli memperkenalkan konsep manusia ekonomi rasional atau homo economicus yang mencoba memaksimalkan kepuasannya (atau utilitas) mengingat kendala yang dihadapinya. Tiga asumsi yang mendasari agen ini adalah; rasionalitas sempurna, kepentingan pribadi yang sempurna dan informasi yang sempurna. Asumsi ini menjadi dasar kerangka keuangan tradisional. 
Tabel 1. Perkembangan Traditional Finance

\begin{tabular}{clll}
\hline No & \multicolumn{1}{c}{ Penulis } & \multicolumn{1}{c}{ Tahun } & \multicolumn{1}{c}{ Temuan } \\
\hline 1 & John Stuart Mill & 1844 & Memperkenalkan konsep "Economic \\
2 & Bernoulli & 1738,1954 & Man" atau "homo economicus" \\
3 & Von Neumann dan Morgentern & 1944 & \\
\hline 4 & Harry Markowitz & 1952 & Teori portofolio Markowitz \\
5 & Treynor, Sharpe dan Lintner & $1962,1964,1965$ & \\
6 & Jan Mossin & 1966 & Hipotesis pasar efisien \\
\hline 7 & Eugene Fama & 1970 &
\end{tabular}

Sumber: (Kapoor \& Prosad, 2017)

Berdasarkan tabel di atas menerangkan bahwa pendekatan tradisional dalam manajemen keuangan sangat dipengaruhi oleh perkembangan ilmu ekonomi. Sehingga tidak heran bahwa awal teoriteori manajemen keuangan berkembangan didasari oleh pandangan ekonom. Setelah berkembang menjadi suatu disiplin ilmu, teori yang mendasarinya pun ikut berkembang dan muncul kelemahan ataupun kekurangan dari pandangan tradisional dalam menjelaskan fenomena yang terjadi.

\section{Teori Keuangan Berbasis Perilaku}

Fama pada tahun 1998 telah menjelaskan bahwa teori keuangan tradisional berpusat di sekitar hipotesis pasar efisien (EMH), yang menyatakan bahwa seseorang tidak dapat secara konsisten mengalahkan pasar. Fama mengklaim bahwa semua informasi yang tersedia dievaluasi secara rasional dan dimasukkan dalam harga yang menyisakan sedikit atau tidak ada peluang arbitrase. Namun, investor yang sangat sukses serta "gelembung ekonomi" yang berkepanjangan sulit dijelaskan dengan EMH, dan banyak yang mempertanyakan validitasnya. Asumsi utamanya bahwa investor adalah rasional dengan informasi sempurna yang membuat keputusan yang memaksimalkan utilitasnya (Miendlarzewska et al., 2019). Berikut dijelaskan tentang perkembangan pandangan keuangan berbasis perilaku.

\section{Tabel 2. Perkembangan Behavioral Finance}

\begin{tabular}{|c|c|c|c|}
\hline No & Penulis & Tahun & Temuan \\
\hline 1 & Herbert Simon & 1955 & Model rasionalitas terbatas. \\
\hline 2 & Festinger, Riecken and Schachter & 1956 & Theory of cognitive dissonance. \\
\hline 3 & Tversky and Kahneman & $\begin{array}{l}1973, \\
1974\end{array}$ & $\begin{array}{l}\text { Memperkenalkan heuristic biases: ketersediaan, keterwakilan, penahan dan } \\
\text { penyesuaian. }\end{array}$ \\
\hline 4 & Kahneman and Tversky & 1979 & Teori prospek, memperkenalkan bias penghindaran kerugian. \\
\hline 5 & Tversky and Kahneman & 1981 & Memperkenalkan bias bingkai (framing effect). \\
\hline 6 & Richard Thaler & 1985 & Memperkenalkan bias akuntansi mental (mental accounting bias). \\
\hline 7 & De Bondt and Thaler & 1985 & Teori reaksi berlebihan di pasar saham. \\
\hline 8 & Barberis, Shleifer and Vishny & 1998 & Model sentimen investor untuk underreaction dan overreaction harga saham. \\
\hline 9 & Meir Statman & 1999 & Teori harga aset perilaku dan teori portofolio perilaku. \\
\hline 10 & Andrei Shleifer & 2000 & $\begin{array}{l}\text { Keterkaitan keuangan berbasis perilaku dengan hipotesis pasar efisien untuk } \\
\text { menemukan bahwa pasar saham tidak efisien. }\end{array}$ \\
\hline 11 & Barberis, Huang and Santos & 2001 & Penggabungan teori prospek dalam harga aset. \\
\hline 12 & Grinblatt and Keloharju & 2001 & Peran faktor perilaku dalam menentukan perilaku perdagangan. \\
\hline 13 & Hubert Fromlet & 2001 & $\begin{array}{l}\text { Pentingnya keuangan berbasis perilaku. Penekanan pada penyimpangan dari } \\
\text { 'homo economicus' atau paradigma tradisional ke paradigma yang lebih } \\
\text { realistis. }\end{array}$ \\
\hline 14 & Barberis and Thaler & 2003 & Survei keuangan berbasis perilaku. \\
\hline 15 & Coval and Shumway & 2006 & $\begin{array}{l}\text { Pengaruh bias perilaku pada harga saham. Pembalikan harga untuk investor } \\
\text { yang bias lebih cepat daripada investor yang tidak bias. }\end{array}$ \\
\hline 16 & Avanidhar Subrahmanyam & 2008 & $\begin{array}{l}\text { Implikasi normatif dari keuangan berbasis perilaku pada investor individu dan } \\
\text { CEO. }\end{array}$ \\
\hline 17 & Richard Thaler & 2008 & Dampak akuntansi mental pada perilaku pilihan konsumen. \\
\hline 18 & Robert Bloomfield & 2010 & $\begin{array}{l}\text { Membandingkan pendekatan perilaku dan keuangan tradisional dalam } \\
\text { menjelaskan inefisiensi pasar. }\end{array}$ \\
\hline 19 & Parag Parikh & 2011 & $\begin{array}{l}\text { Implikasi praktis dari keuangan berbasis perilaku dan sentimen investor } \\
\text { dalam investasi nilai. }\end{array}$ \\
\hline 20 & Uzar and Akkaya & 2013 & Menjelajahi evolusi keuangan berbasis perilaku dari keuangan tradisional. \\
\hline
\end{tabular}

Berdasarkan tabel diatas terlihat jelas bahwa perkembangan keuangan berbasis perilaku sebagai suatu pengatasan atau perbaikan kelemahan atas pandangan keuangan tradisional, menggunakan pendekatan campuran keilmuan seperti psikologi dan sosiologi. 


\section{Neurofinance: Pendekatan Baru Keperilakuan dalam Keputusan Keuangan}

Keuangan berbasis perilaku berfokus pada penerapan perilaku ekonomi dengan kondisi risiko. Artinya, pandangan ini ingin menyelidiki keterkaitan antara orang bertindak dan berinteraksi dalam proses pengambilan keputusan keuangan, dan menafsirkan tindakan ini menurut konsep dan teori psikologi yang ada. Selain itu, dalam bidang ilmu kedokteran dijelaskan tentang neuroscience, yaitu suatu bidang yang menjelaskan tentang sistem saraf dan neuron pada manusia. Kedua perpaduan inilah yang menghasilkan pendekatan baru yang dikenal dengan neurofinance yang bermaksud membuka kotak hitam (black box) otak manusia untuk memahami proses fisiologis (termasuk aktivitas hormonal) yang terjadi ketika orang membuat keputusan keuangan (Ardalan, 2018).

Menurut Srivastava et al. (2019) dan Srivastava et al. (2020) neurofinance merupakan pengembangan dari neuroeconomics yang menjelaskan tentang ilmu saraf dalam hubungannya dengan keputusan ekonomi. Konsep neuroeconomics lebih mencakup hal yang lebih luas dibandingkan neurofinance. Jika dijelaskan lebih lanjut, neuroeconomics merupakan perluasan dari bioeconomics (bioekonomika), yang merupakan gabungan antara disiplin ilmu biologi dengan ekonomi. Berikut dijelaskan perkembangan penelitian terkait neurofinance.

Tabel 3. Perkembangan Neurofinance dan Neuroeconomics dalam Penelitian

\begin{tabular}{|c|c|c|c|}
\hline Tema & $\begin{array}{c}\text { Jumlah } \\
\text { Penelitian } \\
\end{array}$ & $\begin{array}{c}\text { Desain } \\
\text { Penelitian }\end{array}$ & Identifikasi area otak \\
\hline $\begin{array}{l}\text { Area otak yang } \\
\text { terlibat dalam } \\
\text { pengambilan } \\
\text { keputusan }\end{array}$ & 16 & $\begin{array}{l}\text { Konseptual, } \\
\text { empiris, } \\
\text { eksperimental }\end{array}$ & $\begin{array}{l}\text { Belajar } \\
\text { DLPFC, nucleus accumbens, ventral striatum, medial } \\
\text { prefrontal cortex. } \\
\text { Perwakilan } \\
\text { Area ventral tegmental dan substantia niagra, parietal posterior } \\
\text { dan korteks prefrontal superior, jalur pallio-striatal, OFC. } \\
\text { Penilaian } \\
\text { Dorsal anterior cingulate cortex (dACC), amigdala, OFC, } \\
\text { daerah aluerelated (ventral striatum), daerah pertimbangan nilai } \\
\text { (medial prefrontal cortex) dan daerah perkiraan masa depan } \\
\text { (posterior cingulate cortex), DLPFC. } \\
\text { Eksekusi } \\
\text { dACC dan jaringannya, korteks prefrontal, korteks prefrontal } \\
\text { dorsolateral. }\end{array}$ \\
\hline $\begin{array}{l}\text { Area otak yang } \\
\text { terlibat dalam } \\
\text { pengambilan } \\
\text { keputusan } \\
\text { keuangan }\end{array}$ & 6 & $\begin{array}{l}\text { Konseptual, } \\
\text { eksperimental, } \\
\text { empiris }\end{array}$ & $\begin{array}{l}\text { Risiko } \\
\text { Nukleus accumbens, inti berekor. } \\
\text { Penghargaan } \\
\text { Struktur frontal dan striatal medial, korteks orbitofrontal dan } \\
\text { korteks prefrontal ventromedial (VMPFC), striatum dorsal, } \\
\text { nukleus accumbens. } \\
\text { Kemenduaan } \\
\text { OFC, amigdala dan dorsomedial prefrontal cortex (DMPFC), } \\
\text { lateral prefrontal cortex. }\end{array}$ \\
\hline $\begin{array}{l}\text { Eksperimen } \\
\text { dalam } \\
\text { neuroeconomics } \\
\text { dan neurofinance }\end{array}$ & 7 & Eksperimen & $\begin{array}{l}\text { VMF, amigdala, striatum, orbitofrontal cortex, prefrontal } \\
\text { cortex dan anterior cingulate cortex. }\end{array}$ \\
\hline $\begin{array}{l}\text { Implikasi klinis } \\
\text { dari } \\
\text { neuroeconomics } \\
\text { dan neurofinance }\end{array}$ & 11 & $\begin{array}{l}\text { Konseptual, } \\
\text { empiris, } \\
\text { eksperimental }\end{array}$ & $\begin{array}{l}\text { Ini berkaitan dengan penyakit dan disfungsi tertentu di otak, } \\
\text { jadi tidak ada area otak tertentu yang dilaporkan di sini. }\end{array}$ \\
\hline
\end{tabular}

Setelah dikaji dan ditinjau oleh Miendlarzewska et al. (2019), konsep neurofinance memiliki penjelasan istilah atau konsep turunannya. Untuk penelitian di bidang neurofinance dapat menggunakan istilah atau konsep-konsep tersebut, dan dapat pula mengembangkan konsep yang telah ada. Berikut penjelasannya dalam Tabel 4 . 
Tabel 4. Istilah-istilah dalam Neurofinance

\begin{tabular}{|c|c|}
\hline Istilah atau Konsep & Muatan Makna \\
\hline Allele & Bentuk varian dari gen tertentu, yang terletak pada posisi yang sama pada kromosom. \\
\hline BOLD signal & $\begin{array}{l}\text { Menggambarkan tingkat deoxyhemoglobin darah dalam area otak tertentu yang diukur dengan pencitraan } \\
\text { resonansi magnetik fungsional (fMRI). Sinyal ini digunakan untuk secara tidak langsung menyimpulkan } \\
\text { aktivitas neuronal di area otak. }\end{array}$ \\
\hline Dopamine & $\begin{array}{l}\text { Dopamin adalah neurotransmitter - bahan kimia yang dilepaskan oleh neuron untuk mengirim sinyal ke } \\
\text { neuron lain. Jalur dopaminergik dari ventral tegmental area (VTA) di batang otak ke nukleus accumbens (NA) } \\
\text { dan korteks prefrontal sangat penting untuk pembelajaran berbasis penghargaan. }\end{array}$ \\
\hline EEG & $\begin{array}{l}\text { Elektroensefalografi menggunakan elektroda yang ditempatkan di kulit kepala untuk merekam aktivitas listrik } \\
\text { otak secara non invasif dengan presisi temporal tinggi (milidetik). }\end{array}$ \\
\hline fMRI & $\begin{array}{l}\text { Pencitraan resonansi magnetik fungsional mengukur perubahan tingkat oksigen darah di dalam otak secara } \\
\text { non invasif, dengan presisi spasial yang tinggi. Aktivitas saraf yang berhubungan dengan peristiwa atau } \\
\text { stimulus diukur dengan membandingkan sinyal BOLD. }\end{array}$ \\
\hline Genetic polymorphisms & $\begin{array}{l}\text { Suatu gen dikatakan polimorfik jika lebih dari satu alel dapat hadir pada lokus genetik tertentu dalam suatu } \\
\text { populasi. }\end{array}$ \\
\hline Gray matter & $\begin{array}{l}\text { Jaringan pusat sistem saraf. Dibandingkan dengan materi putih, ia mengandung lebih banyak badan sel saraf } \\
\text { dan lebih sedikit saluran akson mielin jarak jauh (yang penting untuk mentransfer informasi melintasi jarak } \\
\text { jauh). }\end{array}$ \\
\hline Homozygous & Homozigot mengacu pada memiliki dua salinan alel yang sama untuk sifat tertentu. \\
\hline $\begin{array}{l}\text { Hypothalamic-pituitary- } \\
\text { adrenal (HPA) axis }\end{array}$ & $\begin{array}{l}\text { Sumbu HPA adalah jaringan kompleks yang mengatur respons stres dan terdiri dari tiga kelenjar endokrin: } \\
\text { hipotalamus, kelenjar pituitari, dan kelenjar adrenal. }\end{array}$ \\
\hline $\begin{array}{l}\text { Monoamine oxidase-A } \\
\text { (MAOA) }\end{array}$ & $\begin{array}{l}\text { Enzim pada manusia yang mendegradasi neurotransmiter amina seperti dopamin yang dikodekan oleh gen } \\
\text { MAOA. }\end{array}$ \\
\hline $\begin{array}{l}\text { Monozygotic and } \\
\text { dizygotic }\end{array}$ & $\begin{array}{l}\text { Anak kembar bisa jadi monozigot atau dizygotic. Kembar monozigot berkembang dari satu sel (zigot), yang } \\
\text { membelah dan membentuk dua embrio. Kembar dizigotik dikembangkan dari dua zigot yang berbeda. }\end{array}$ \\
\hline Reactiontime & $\begin{array}{l}\text { Variabel yang sering dinilai dalam eksperimen psikologis untuk membuat kesimpulan tentang proses } \\
\text { psikologis. Biasanya dihitung sebagai waktu sejak permulaan stimulus ke respon motorik subjek. }\end{array}$ \\
\hline Reinforcement learning & $\begin{array}{l}\text { Menjelaskan bagaimana seorang agen - melalui interaksinya dengan lingkungan - belajar untuk mengambil } \\
\text { tindakan seperti memaksimalkan imbalan kumulatif di masa depan. Dalam pembelajaran dan perilaku, ini } \\
\text { disebut sebagai penguatan positif dan melibatkan stimulus positif (nafsu makan). Dalam penguatan negatif, } \\
\text { perilaku diperkuat karena mencegah stimulus negatif (permusuhan). }\end{array}$ \\
\hline Resting-stateactivity & $\begin{array}{l}\text { Istilah ini biasanya mengacu pada aktivitas neuronal di otak yang diukur dengan metode neuroimaging } \\
\text { (misalnya, fMRI) selama keadaan di mana tidak ada tugas eksplisit yang dilakukan. }\end{array}$ \\
\hline Risk prediction error & Sebuah pelacakan sinyal komputasi berubah dalam jumlah variabilitas (risiko). \\
\hline Serotonin $(5-\mathrm{HT})$ & $\begin{array}{l}\text { Serotonin adalah neurotransmitter yang berperan dalam mengatur suasana hati, emosi dan pemrosesan emosi } \\
\text { serta pengambilan keputusan. }\end{array}$ \\
\hline TMS & $\begin{array}{l}\text { Stimulasi magnetik transkranial adalah metode yang digunakan untuk merangsang daerah kecil dari lapisan } \\
\text { superfisial otak. Generator medan magnet, atau "kumparan," menghasilkan arus listrik kecil di wilayah otak } \\
\text { tepat di bawah kumparan melalui induksi elektromagnetik. Bergantung pada frekuensi rangsangan, baik } \\
\text { potensiasi atau penekanan aktivitas kortikal dapat diinduksi. }\end{array}$ \\
\hline
\end{tabular}

Sumber: (Miendlarzewska et al., 2019)

\section{Neurofinance: Peluang Riset di Masa Menda- tang}

Jika Tabel 4 tersebut dijabarkan dalam bentuk grafik terlihat bahwa masih sangat minim penelitian terkait neurofinance. Penelitian terkait neurofinance yang tercatat pada penelitian Srivastava et al., (2019) berjumlah 15 persen penelitian tentang area otak yang terlibat dalam pengambilan keputusan keuangan serta secara jumlah masih terbatas publikasi terkait neurofinance. Srivastava et al. (2019) juga menjelaskan bahwa "...there may be studies that are not included in this meta-analysis and could be undertaken by future research studies".

Neurofinance, dalam tahap awal penelitian, berkaitan dengan pemahaman proses neurologis di otak investor saat membuat keputusan keuangan (Teall, 2018). Hal ini menunjukkan bahwa penelitian neurofinance masih berada di fase permulaan, sehingga perlu penelitian selanjutnya yang menjelaskan neurofinance secara lebih empiris. 


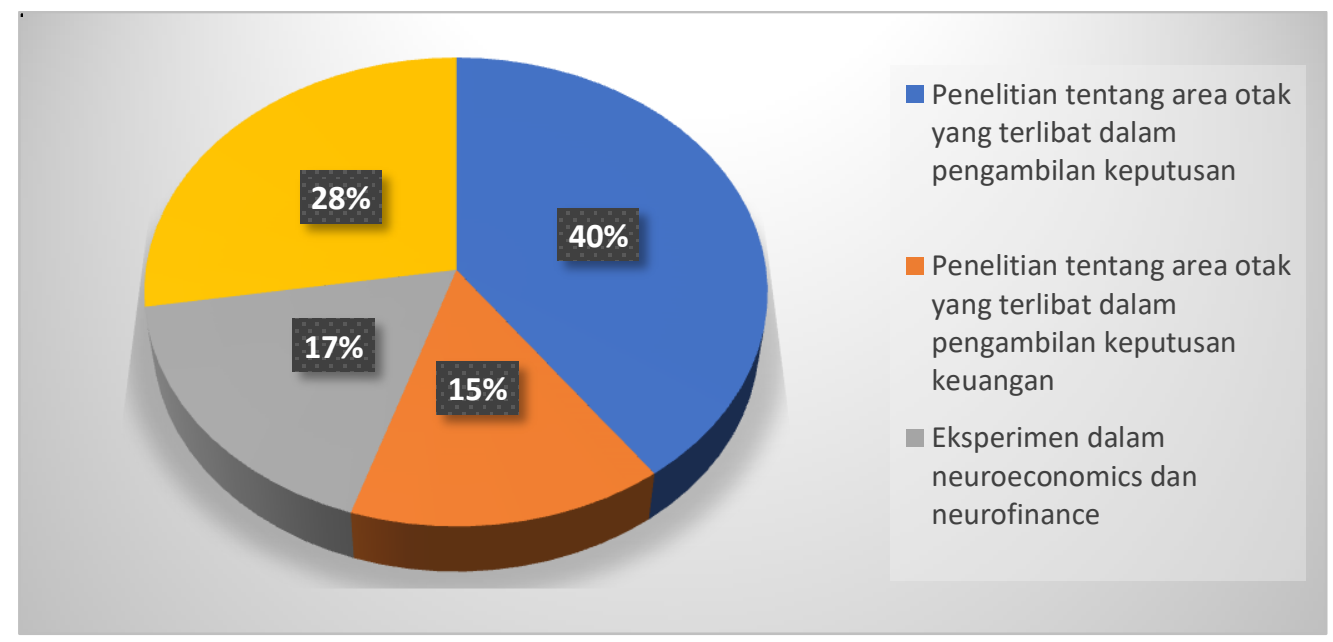

Gambar 2. Diagram Lingkar Penelitian tentang Neurofinance

Penulis melihat bahwa neurofinance sebagai sebuah pandangan baru yang menjadi tren atau arah riset modern keuangan yang mengaitkan antara bidang keuangan dengan bidang keilmuan lainnya. Sehingga dapat disimpulkan bahwa penelitian manajemen keuangan saat ini adalah interdisiplin, artinya keuangan dapat dikaitkan dengan disiplin ilmu lain. Selain, neurofinance, penulis melihat terdapat pandangan baru lainnya seperti: internet finance yang mengaitkan keuangan dengan teknik informatika (Zhong \& Jiang, 2020), sustainable supply chain finance yang mengaitkan manajemen operasi dengan keuangan (Abdel-Basset et al., 2020) dan sebagainya.

Fase ketiga yang dijelaskan pada judul artikel menunjukkan bahwa neurofinance merupakan sebuah pendekatan lintas keilmuan yang terjadi saat ini. Tabel dibawah ini dapat menjelaskan tentang tiga fase teori manajemen keuangan.

Tabel 5. Tiga Fase Teori dalam Manajemen Keuangan

\begin{tabular}{lll}
\hline \multicolumn{1}{c}{ Fase Pertama } & \multicolumn{1}{c}{ Fase Kedua } & \multicolumn{1}{c}{ Fase Ketiga } \\
\hline Traditional finance & Behavioral finance & Interdisciplinary finance \\
\hline Merupakan peletak dasar teori & Merupakan pelengkap traditional & Merupakan pendekatan cempuran \\
manajemen keuangan. Seperti: teori & finance, dimana pandangan keuangan & bidang ilmu andata manajemen \\
keagenan, teorema MM tentang & berbasis perilaku menunjuk pada & keuangan dengan bidang ilmu lainnya \\
struktur modal dan dividen tidak & aspek psikologis investor atau & seperti kedokteran, sains dan \\
relevan, teori portofolio, hipotesis & masyarakat keuangan. teori pada & teknologi sehingga menghasilkan \\
pasar efisiensi, dll & pendekatan ini adalah: teori prospek, & konsep dan pandangan baru. Seperti: \\
& framing effect, dll & neurofinance, internet finance, dll
\end{tabular}

\section{SIMPULAN}

Berdasarkan penjelasan tentang evolusi teori dalam manajemen keuangan terlihat sebuah perjalanan panjang sejak tahun 1844 sampai saat ini, menunjukkan bahwa bidang keuangan merupakan salah satu bidang yang sangat berkembang.

Pandangan tradisional mengawali langkah perkembangan teori tersebut dan dilanjutkan dengan pandangan keperilakuan yang melihat adanya kelemahan pada asumsi-asumsi yang dijelaskan pada pandangan tradisional.

Setelahnya masih terdapat kekurangan dari pandangan keperilakuan terkait menjelaskan ketidak rasionalan seorang investor dalam mengambil keputusan.

Kemudian munculah konsep neurofinance sebagai sebuah area penelitian yang menghubungkan ilmu kedokteran dan saraf manusia dengan keuangan.

Pada kesimpulan ini juga, penulis membagi evolusi teori dalam bidang ilmu manajemen keuangan dalam tiga fase, yaitu fase pertama yaitu dimulai dengan pandangan tradisional, lalu bergeser ke pandangan kedua tentang keuangan berbasis perilaku dan pada saat ini memasuki fase ketiga yang interdisciplinary finance (keuangan interdisipliner). 


\section{DAFTAR PUSTAKA}

Abdel-Basset, M., Mohamed, R., Sallam, K., \& Elhoseny, M. (2020). A novel decisionmaking model for sustainable supply chain finance under uncertainty environment. Journal of Cleaner Production, 269, 122324. https://doi.org/10.1016/j.jclepro.2020.122324

Ardalan, K. (2018). Neurofinance versus the efficient markets hypothesis. Global Finance Journal, 35(July), 170-176. https://doi.org/10.1016/j.gfj.2017.10.005

Bloomfield,R.(2010).SSRN-id1596888. Traditional vs. Behavioral Finance (Issue April).

Huang, J. Y., Shieh, J. C. P., \& Kao, Y. C. (2016). Starting points for a new researcher in behavioral finance. International Journal of Managerial Finance, 12(1), 92-103. https://doi.org/10.1108/IJMF-05-2015-0111

Kapoor, S., \& Prosad, J. M. (2017). Behavioural Finance: A Review. Procedia Computer Science, 122, 50-54. https://doi.org/10.1016/j.procs.2017.11.340

Miendlarzewska, E. A., Kometer, M., \& Preuschoff, K. (2019). Neurofinance. Organizational Research Methods, 22(1), 196-222. https://doi.org/10.1177/1094428117730891

Paddock, J., Copeland, T. E., \& Weston, J. F. (1980). Financial Theory and Corporate Policy. In The Journal of Finance (Vol. 35, Issue 3). https://doi.org/10.2307/2327506

Srivastava, M., Sharma, G. D., \& Srivastava, A. K. (2019). Human brain and financial behavior: a neurofinance perspective. International Journal of Ethics and Systems, 35(4), 485503. https://doi.org/10.1108/IJOES-02-20190036

Srivastava, M., Sharma, G. D., Srivastava, A. K., \& Kumaran, S. S. (2020). What's in the brain for us: a systematic literature review of neuroeconomics and neurofinance. Qualitative Research in Financial Markets, 12(4), 413-435. https://doi.org/10.1108/QRFM-10-2019-0127

Teall, J. L. (2018). The Mind of the Investor. In Financial Trading and Investing. https://doi.org/10.1016/b978-0-12-8111161.00010-6

Zhong, W., \& Jiang, T. (2020). Can internet finance alleviate the exclusiveness of traditional finance? evidence from Chinese P2P lending markets. Finance Research Letters, July, 101731.

https://doi.org/10.1016/j.frl.2020.101731 
86 Coopetition, Vol XII, Nomor 1, Maret 2021, 79 - 86

(E-ISSN : 2615-4978, P-ISSN : 2086-4620) 